NBER WORKING PAPER SERIES

\title{
THE DETERIORATING FISCAL SITUATION AND AN AGING POPULATION
}

\author{
Robert Dekle \\ Working Paper 9367 \\ http://www.nber.org/papers/w9367
NATIONAL BUREAU OF ECONOMIC RESEARCH 1050 Massachusetts Avenue
Cambridge, MA 02138 \\ December 2002
}

I thank Magnus Blomstrom, Jennifer Corbett, Fumio Hayashi, Anil Kashyap, and other participants of the NBER conference on "Structural Impediments to Growth in Japan" for helpful comments. I also thank Mr. Akira Furukawa for advice on data collection, and Larry Meissner for editing the manuscript. Any remaining errors are my own. The views expressed herein are those of the authors and not necessarily those of the National Bureau of Economic Research.

(C) 2002 by Robert Dekle. All rights reserved. Short sections of text, not to exceed two paragraphs, may be quoted without explicit permission provided that full credit, including $(\subset$ notice, is given to the source. 
The Deteriorating Fiscal Situation and an Aging Population

Robert Dekle

NBER Working Paper No. 9367

December 2002

JEL No. E6, H5, H6

\title{
$\underline{\text { ABSTRACT }}$
}

Japan's deteriorating fiscal situation has attracted international attention. I assess what current Japanese government policies mean for the future of public debt and the economy in general, given the inevitable aging of the population. I review how Japan got into this current fiscal mess, and then perform an analysis of some debt dynamics. With unchanged fiscal policies, Japan's public debt will rise to between $260 \%$ and $380 \%$ of GDP in 2030 , and to between $700 \%$ and $1300 \%$ in 2040 -clearly unsustainable levels. For the debt to be sustainable, significant increases in taxes, or cuts in government spending are necessary.

\author{
Robert Dekle \\ Department of Economics, USC \\ Los Angeles, CA 90089 \\ dekle@usc.edu
}


Japan' s deteriorating fiscal situation has attracted world-wide attention. If the situation does not improve, the resulting huge public debt is expected to sharply increase Japanese interest rates, lower Japan's international creditworthiness, and adversely affect the welfare of future generations. In this chapter I assess what current Japanese government fiscal policies mean for the future of public debt and the economy in general, given the inevitable aging of the population.

Owing to a very weak domestic economy, which lowered tax revenues and raised government spending, Japan's fiscal balance has deteriorated dramatically. The budget, in surplus until 1992, turned negative in 1993 and the deficits have continued to worsen, reaching almost $11 \%$ of GDP in 1998. Debt ballooned: the government debt-to-GDP ratio increased by almost half from 1991 to 1997 and by another quarter in the two years after that. By 2000, Japan had the largest ratio among OECD countries.

$$
\text { Japan's fiscal situation continues to look grim, especially given the }
$$
demographic situation. Population aging is expected to slow economic growth and raise future government health care and social security expenditures. Projections of the country' s population and the percentage of the total population that is elderly (Ministry of Health and Welfare 1998) are plotted in Figure 1.

The population over 65 has grown rapidly, and now stands at about 15\%. By 2020 , its percentage is expected to approach $25 \%$, and by 2050, 33\%. These rates of aging are much higher than, for example, in the United States, where only about 15\% of the population will be over 65 by 2025 .

This chapter first reviews how Japan got into its current fiscal mess during the 1990s. This is followed by an analysis of debt dynamics. With unchanged fiscal policies, Japan' s public debt will rise to between $260 \%$ and $380 \%$ of GDP in 2020 , and to between $700 \%$ and $1300 \%$ in 2040 - clearly unsustainable levels. For the debt to be sustainable, significant increases in taxes, or cuts in government spending are necessary.

Next, the government' s fiscal agendas are briefly discussed. The focus has been on spending cuts rather than tax increases. However, most of the proposed cuts were postponed or abandoned as the government sought to stimulate demand in light of the very weak domestic economy. The results of a simulation exercise that explicitly incorporates the effects of an aging Japanese population are then presented. In the simulation, I explicitly model the interplay between government fiscal policies and household and corporate behaviors. This is important, because fiscal policies clearly can affect private behavior, and these changes in private behavior may, in turn, 
influence the dynamics of government debt. The simulation shows that, absent cuts in government spending, for the government debt to be sustainable, taxes would need to increase from the current $28 \%$ of GDP to over $40 \%$ by 2020. The tax increases and the inevitable aging of the population are projected to sharply reduce household saving rates. As the labor force declines, and the need to equip workers with capital decreases, corporate investment rates also are projected to fall.

\section{The Current Japanese Fiscal Situation}

Government saving declined and public investment rose in the 1990s (Table 1). These trends were caused by the recession, as well as by structural changes. The recession and the decline in the rate of economic growth lowered tax revenues. Structural changes that worsened government saving included tax reforms that lowered tax elasticities and thus tax revenues; and the aging of the population, which raised social security and health care expenditures. In the 1990s the government also boosted public investment in an attempt to stimulate aggregate demand. These changes in government saving and public investment led to a sharp deterioration in government finances. The resulting increase in outstanding bonds has raised concerns about fiscal sustainability and calls for fiscal reform.

\section{1 Government Saving}

Government saving can be divided into its "full-employment" and "cyclical" components. In a recessionary environment government spending usually increases because of higher unemployment and social welfare benefits. However, owing to the low cyclical variability of Japanese unemployment and social welfare benefits, government spending increases in Japan during the 1990s recession were capped. Also during recessions, tax revenues can decline because of lowered incomes. I estimate that during 1990-99, Japan's “full-employment” government saving was about 2.6\% of GDP, compared to an actual level of $2.0 \%$, making the "cyclical" component $-0.6 \%$. Thus, much of the decline in government saving in the late 1990s was from structural factors, such as tax reductions, rather than from "automatic stabilizers." 1

\footnotetext{
1 I estimate "full-employment" government saving by regressing government saving on the output gap and a constant, using quarterly data from 1990 to 1999. I interpret the estimated value of the constant - which is the government saving rate when the output gap is equal to zero - as

"full-employment" government saving. The estimated value of the constant equaled 2.6\%.
} 
Government saving also can be broken down into the social security surplus, the surplus in other categories, and health care expenditures (Table 2). The social security surplus (benefits minus contributions) fell from about 1.3\% of GDP in the early 1990s to about $0.4 \%$ in 1999 because of the recession (lowering contributions) and increase in the number of elderly (raising benefits). Government health care expenditures rose from about 3.6\% of GDP in the early 1990s to about 4. 3\% in 1999, mainly owing to the increase in the elderly, who use most of the hospital services. However, the health care expenditure-to-GDP ratio in Japan is still smaller than in the United States (6.6\%) and Germany (7.7\%). The remaining category of government saving includes such items as education, defense, and policing and firefighting. Saving in this category declined sharply from $9.5 \%$ of GDP to $3.9 \%$ because of the fall in income and consumption tax revenues.

\section{2 Public Investment}

During the 1990s the Japanese government passed 10 stimulus packages in an attempt to jump-start the stalled economy. The most important component of these packages was public works, which are included in public investment. However, the actual increases in the late 1990s were rather moderate compared to the prominent and headline grabbing role of public works in the stimulus packages.

There are two reasons actual public works fell short of announced levels. First, the central government assigned roughly two-thirds of the increased public works spending to local governments without providing a commensurate increase in funding. The capacity of local governments to expand public investment was affected by their poor financial situation, and the continued rise in public investment has increasingly been financed through local bond issues. The amount of outstanding local government bonds increased from $12 \%$ of GDP in 1990 to $22 \%$ in 1997 . Many local governments surpassed the legally allowed threshold of bonds outstanding and were put under bond issuance restrictions by the central government. Second, some of the public investment funds provided by the stimulus packages remained unused because of poor project implementation. Ishii and Wada (1998) calculated that only 60\% to

Ihori, Nakazato, and Kawade (2002) also show that the “cyclical” component of government saving was small. They find that much of the decline in government saving can be attributed to the decline in "trend" output, rather than to the decline in "cyclical" output. The low cyclical variability of government saving is corroborated in an IMF study showing that a one-percentage point increase in the output gap translated into an increase of the cyclical deficit by about $0.33 \%$ of GDP, which is about half of the deficit response in other OECD countries (Muhleisen, 2000). 
$70 \%$ of the packages' public works had been translated into additional demand by the during late 1990s. ${ }^{2}$

\section{3 Government Debt and Liabilities}

The late 1990s decline in government saving and rise in public investment led to a surge in government debt, as shown in Table 2. The fiscal surplus declined almost continuously in the 1990 s until reaching about minus $11 \%$ in 1998 . The 1999 improvement has not carried over in the 2000s. Correspondingly, the ratio of debt to GDP has risen sharply. By international standards, Japan's gross debt-to-GDP in 1999 was the highest among the G-7 countries; Italy' s was $115 \%$ and the United States' was $62 \%$.

The fiscal balance as a percentage of GDP is less than the difference between the government saving ratio and the public investment ratio (Table 1, column 2 minus column 4) by about two percentage points, mainly because of the inclusion of net government land purchases in the fiscal balance. During the 1990s the government bought significant amounts of land from the private sector to prop up land prices.

Because of the partly funded nature of the Japanese pension system, as well as the government' s major role in financial intermediation, the Japanese government holds significant assets, keeping net debt-to-GDP at a moderate level and lower than in other G-7 countries. However, the assets of the social security system are more than offset by future pension obligations. Therefore, some, including the OECD and the IMF, exclude social security net assets when assessing Japan's debt situation. As a result, Japan' s net debt excluding social security net assets, at 85\%, is significantly higher than the United States' 60\%, and Germany's 53\%.

\section{Projecting the Debt Burden}

Table 3 depicts the dynamics of the debt-to-GDP ratio under three scenarios about tax, public investment, and spending policies and two assumptions regarding real interest rates.

In scenario 1, current policies continue; the debt dynamics are clearly "unsustainable" : even under optimistic interest rate expectations, debt exceeds

\footnotetext{
${ }^{2}$ Tracking public works budgets in Japan is tricky because so much of the spending is outside the regular budget of the central government. Thus, looking just at the "general expenditures" data there actually were declines each year from fiscal 1994 to 1999.
} 
$250 \%$ of GDP by 2015. (I define "unsustainable" as meaning that the debt-GDP ratio goes to infinity. ) Scenario 2, like Scenario 1, assumes government spending and public investment policies remain unchanged, but also assumes the government sufficiently raises taxes so that the debt-to-GDP ratio stabilizes and eventually declines. Stabilization with $3 \%$ interest rates comes around $2015-25$, at $140 \%-150 \%$, and with $6 \%$ interest is in the 2010s at just over $200 \%$

As described later, the government is undertaking fiscal reform, and is planning deep cuts in spending and public investment. Scenario 3 assumes the reforms are carried out. This leads to dramatically improved debt dynamics. Still, the debt-to-GDP ratio continues to grow, albeit significantly more slowly than in Scenario 1 , as taxes are not sufficient to cover the government's total expenditures (including the interest payments on the outstanding debt). Note that at $6 \%$ interest the debt ratio increases steadily but at $3 \%$ it is fairly stable during 2005-35. This is because at 6\% interest, debt grows much faster than GDP.

At $3 \%$ interest rates, spending cuts (Scenario 3) produces lower ratios than increased taxes (Scenario 2) but, at 6\% rates, by 2030 the ratio in Scenario 3 is higher. The remainder of this section more fully explains the scenarios.

\section{1 Assumptions}

Because unfunded future social security liabilities are already accounted for in the scenarios, the net figure of $45 \%$ is taken as the initial ratio of debt-to-GDP.

The dynamics of the debt-to-GDP ratio are highly sensitive to assumptions regarding the real interest rate and the real GDP growth rate. Other things being equal, the higher the real interest rate, the higher the ratio; and, the higher the real GDP growth rate, the lower the ratio.

Consistent with most forecasters' projections of real GDP growth for the next 20 years of between 1\% and 1. 5\% annual1y (Japan Center of Economic Research 2001), the analysis here assume an average of 1.2\% annually between 2000 and 2040 .

There are two real interest rate assumptions. The first is $3 \%$ because, since the early 1980s, Japanese real interest rates have averaged about 3\% and that rate is used in other studies to project the path of future Japanese government deficits (IMF 2000, Jinno and Kaneko 2000). However, in the future, the Japanese government may no longer be able to borrow at such a low rate, and may have to borrow at higher international real rates. Thus, the second assumption is 6\%, which reflects the average real cost of borrowing in international financial markets in the 1990s. Note that since 2000, the nominal interest rate on five- to six- year maturity Japanese Government Bonds (JGBs) has been close to 4\%. Because inflation rates are essentially 
zero, the real rate on Japanese government borrowing is now close to $4 \%$.

\subsection{The Scenarios}

Scenario 1, the baseline, is that future government policies essentially remain unchanged. With regards to tax and public investment policies, the assumption is that the government keeps the tax-to-GDP and public investment-to-GDP ratios at current (average, 1996-99) levels. With regards to government spending policies, projections are more complicated, as population aging affects future government social security and health care expenditures. It is assumed that the government keeps age-specific expenditure patterns for social security, health care, and education constant at current (average 1996-99) real levels. That is, if the average 67-year old receives 190, 000 yen in government health care in 2000, the average 67-year old in 2035 will receive the same inflation-adjusted amount. In addition, it is assumed that eligibility for social security remains 60 , and for old age health care benefits, remains 70 . Other government spending, mainly defense, policing, and administration, are assumed to always equal the average 1996-99 ratio to GDP of 5.6\%. ${ }^{3}$

Under these spending assumptions, Table 4 shows the projections of total government spending in 1995 yen and as a share of projected GDP. The shift in the age distribution towards the elderly significantly raises government spending. In particular, in 2035 the population over 65 increases significantly, leading to a spike in social security and health care spending. These spending projections (after rounding) are used directly in Scenarios 1 and 2.

In Scenario 3, in 2015 the age of eligibility for social security is raised to 65 , and for old-age health care benefits, to 75 . Other spending is reduced by $10 \%$ in 2005. These changes in social security and in old-age health care correspond roughly to what are actually included in the fiscal reform agendas. Public investment is cut especially sharply - to 3\% of GDP by 2005 - the level prevailing in the United States (Muhleisen, 2000).

\section{The True Size of Government Liabilities}

\footnotetext{
${ }^{3}$ For social security, I divided average social security expenditures in 1996-99 by the population over age 60. For health care, I allocate average health care spending in 1996-99 to different ages, using the age-specific expenditure patterns reported by in Ishi (2000). For education, I divide average education spending in $1996-99$ by the population aged 5-20.
} 
Because of unfunded liabilities, the government's true net obligations today may be substantially higher than the reported $45 \%$ of GDP. In addition to unfunded social security obligations, there are three main sources of unfunded liabilities. These are potential losses on government assets, explicit government guarantees of private sector lending, and implicitly guaranteed private sector loans.

Potential losses on government assets are significant. A portion of the government' s assets represent soft loans that may not be repaid. Many large public or joint public-private infrastructure projects financed from Fiscal Investment and Loan Program (FILP) loans generate less revenue than budgeted, which may imply significant contingent liabilities of the government. Doi and Hoshi (this volume) show that many public corporations and local governments carrying out infrastructure projects are essentially insolvent. They estimate the amount of potential government bailout of the FILP and the local governments as over 15\% of 2000 GDP.

The second source of unfunded liabilities are explicit government guarantees of private sector lending. Explicit guarantees are extended by the FILP and other government entities to encourage lending by private financial institutions. Examples are guarantees of bank deposits by the Deposit Insurance Corporation and of lending by credit cooperatives to smal1- and medium- enterprises. Although these do not entail fresh government lending, should the guaranteed loans not be repaid, the government must cover them from its budget. The total amount of outstanding government-guaranteed bonds and loans amounted to about 10\% of GDP in 2000. Although historically only about $1 \%$ of such loans are never repaid, the percentage could soar if the Japanese economy worsens (Bayoumi 1998).

In addition to explicit government guarantees, there are implicitly guaranteed private sector loans. Historically, the Japanese government has shown a willingness to make good the irrecoverable loans of private financial institutions. In 2000 public funds spent recapitalizing the banking system and included in government spending totaled about 8 yen trillion ( $2 \%$ of GDP). This willingness represents implicit guarantees, and these guarantees are (unfunded) contingent liabilities of the government. Despite the large amount of public funds already spent, Fukao (this volume) argues that the Japanese government may have to expend additional funds to recapitalize the private banking system within the next two or three years. In that case, the cost to taxpayers would be equal to the estimated losses on problem loans minus the loan loss reserves of the banking sector. Fukao calculates that this cost to taxpayers would be about 2\% of GDP (7.6 trillion yen at March 2001). 


\section{Fiscal Reform Measures}

To restrain future increases in the government' $\mathrm{s}$ debt and in other liabilities, the government proposed several fiscal reform measures in the 1990s. However, most of the measures were postponed or abandoned as the government sought to stimulate demand in light of the very weak domestic economy. The 1997 Fiscal Structural Reform Law, with its goal of eliminating fiscal deficits by 2003, is the most significant measure.

The main instruments in the 1997 law were cuts in government consumption and investment, rather than tax increases. Public investment spending was to be cut by $7 \%$ in 1998, with zero nominal growth until 2001; and energy, education, and overseas development assistance were to be cut by $10 \%$ in 1998, with annual reductions until 2001 (Ishi 2000, p 149). However, with the severe recession of 1997, fiscal consolidation was put on hold, and a wide range of pump-priming measures were introduced. In particular, rather than declining, public investment for 1998 was increased by over $10 \%$.

Areas where the 1997 law had an effect were health care and social security. In 1997 the contribution rate and co-payments by patients for government health insurance schemes were increased sharply (Ishi 2000). In particular, patients aged 70 and above are required to pay a fixed proportion (10\%) of their medical costs. The government also capped prescription drug prices, which are very high in Japan.

In 2000, a social security reform bill based on the 1997 law passed the Diet. The bill contains provisions to cut lifetime benefits by about $20 \%$. Specifically, benefits for new retirees will be cut by 5\%; the age of eligibility will, from 2013, be raised gradually from 60 to 65 ; and benefits will be subject to an earnings test. Analysts have estimated that these reforms will reduce government unfunded social security liabilities from the current $60 \%$ of GDP to $30 \%$ of GDP (IMF 2000).

The government is planning to implement further cuts once the economy recovers

fully. A political commitment has been made to cap government deficit bond issues at 30 trillion yen (6\%) of GDP in 2002. Although "deficit" bonds reflect only a portion of total government borrowing, this ceiling should help lower future fiscal deficits.

As stipulated in the 1997 law, public investment is due for further cuts. Criticism has been directed at the economic value of public works projects, as well as contracting procedures. To address the efficiency issues, new cost-benefit guidelines for reviewing projects were announced. Contracting procedures also have been reformed. Public works projects in fiscal 2002 (ends March 2003) were scheduled to be cut by $10 \%$, although it unclear if the cuts will materialize. The government 
intends to change the form of public works from traditional construction projects to broader social infrastructure investment. This includes environment and energy-related projects, telecommunications networks, scientific research, nursing homes, and the like.

With regards to health care, contribution rates and co-payments, especially by the elderly, are to increase further. The stated goal is to restrict the growth of medical costs of the elderly to no more than the rate of inflation. In this regard, the Diet has just passed a law to increase the health care co-payment ratio from 20 percent to 30 percent. The age of eligibility for elderly medical care eventually will also be raised from 70 to 75 . Further cuts are also planned in social security. There are even suggestions that average benefits be reduced by another $40 \%$ to avoid large increases in future contribution rates (Sakurai 1998).

\section{Interaction with Private Behavior}

The calculations of Japanese government debt reported in Table 3 implicitly assume that private behavior is unaffected by government fiscal policies. However, in reality, fiscal policies clearly influence private behavior, and changes in private behavior may, in turn, affect the dynamics of government debt. For example, government taxation can alter the path of household saving and corporate investment which, in turn, can change tax collections. To better project the dynamics of government debt under an aging population, the interplay between fiscal policy and household and corporate behavior should be accounted for. To this end, I have constructed a simulation model.

\section{1 A Simulation Model}

In Dekle (2002) I projected the path of the government budget, together with the path of private saving and investment in Japan, using a formal dynamic economic growth model. Admittedly, the assumptions underlying the model's projections are somewhat special, but they are plausible and provide a fairly rigorous basis for analyzing policy implications.

Specifically, I closely followed Cutler, Poterba, Sheiner, and Summers (1990) in examining the impact of changing demographics on government debt, private investment, and saving. I simulated the growth model using the future path of demographics, summarized by the support ratio, which is the ratio of the labor force to the total population. The support ratio is projected to fall by $20 \%$ in the next 
50 years. $^{4}$

In the model, firms maximize profits using labor, private capital, and public capital as inputs to produce output (GDP). Firms are blessed with technical progress that raises the efficiency of labor by $1.2 \%$ a year. Private capital can be loaned or borrowed at a constant international rental (real interest) rate of $6 \%$.

I show that if the support ratio is constant, output per capita grows at $1.2 \%$ per year. A declining support ratio, however, implies output per capita growth of less than $1.2 \%$, as there are fewer workers to support the population.

Households are assumed to maximize not only their own welfare, but also the welfare of their children. Preferences are such that households desire to keep consumption per capita growing at a constant rate ( "consumption smoothing" ). The model shows that by borrowing from international capital markets, households can indefinitely maintain growth in consumption per capita of $1.2 \%$. Thus, although consumption per capita grows at $1.2 \%$, output per capita grows at less than $1.2 \%$ when the support ratio is declining. Thus, a declining support ratio raises the ratio of consumption to output, and lowers the private saving rate.

In the model, the government performs three actions, always taking into account the effect of these actions on private behavior. First, it supplies "goods and services" to households in the form of social security benefits, health care, and other services. Government expenditures of this form are assumed to be determined by the age structure of the population, and the time path of these expenditures is taken as given (from Table 4).

Second, the government carries out public investment to supply public capital to firms. The government is assumed to choose the time path of public capital optimally, taking into account the offsetting effects of this public capital on GDP growth and on the public debt burden.

Third, the government levies a tax on households to pay for its spending and public investment, and this tax imposes efficiency losses on households. Given these efficiency losses, the model shows that the government will choose to levy a tax that is not fluctuating and is growing at the same $1.2 \%$ annual rate as consumption ( "tax

${ }^{4}$ That is, $\frac{\mathrm{LF}}{\mathrm{POP}}=\frac{\sum_{\mathrm{i}=20}^{64} \mathrm{~N}_{\mathrm{i}}}{\sum_{\mathrm{i}=1}^{99} \mathrm{~N}_{\mathrm{i}}}$, where $\mathrm{N}_{\mathrm{i}}$ is the number of people of age $i$.

Dekle (2002) can be downloaded from my web site:

[www. usc. edu/dept/LAS/economics/Pages/faculty/fac_pages/web_dekle.htm]. 
smoothing" ). For the government to remain solvent, the present value of these taxes must be at least as large as the current stock of public debt plus the present value of all future government spending and public investment. That is, if government tax revenues are insufficient to cover government spending today, then tax revenues must exceed government spending in the future.

\section{Projections of Government Debt}

The path of government debt and of private saving and investment from 2000 to 2040 are presented in Table 5, using the results of the model. Under tax smoothing, taxes per capita increase at a constant rate, while output per capita grows at a slower rate; thus, the tax-to-GDP ratio rises over time. However, the actual tax rate in the starting year (2000), 28\% of GDP, is lower than the 33\% necessitated by tax smoothing and the requirement that the government be solvent. To satisfy the government' s solvency constraint, taxes per capita are allowed to increase more rapidly between 2000 and 2015, and then increases in taxes per capita are smoothed from 2015 onward. By 2040, tax rates need to increase to almost 50\% of GDP for the government to recoup its current outstanding debt, projected future spending (from Table 4), and projected future public investment (Table 5).

Government saving rates rise from about $1 \%$ to $2 \%$ of GDP in 2000 to about $10 \%$ in 2020 owing to the increased tax receipts. Government saving rates decline somewhat in 2035 because of increases in social security and health care spending caused by the spike in the over-65 population in 2035. Because of falling public investment and high government saving, the fiscal surplus (government saving minus public investment) turns positive after 2020, and rises thereafter. Thus, the decline in the government net debt-to-GDP ratio is fairly rapid between 2020 and 2040 .

Private saving rates are projected to fall a few percentage points until 2010, and then fall rapidly from 2010 to 2040. This pattern is a result of declines in the support ratio and increases in tax rates, which reduces disposable income. Although consumption per capita grows at a constant 1.2\%, output per capita grows at a slower rate (as the support ratio declines), thus lowering saving rates. In effect, consumers are seeking to smooth their consumption when income is growing very slowly by lowering their saving rates.

As the labor force shrinks, the need to equip workers with capital equipment decreases, and both private and public investment rates decline. The private investment rate declines from $20 \%$ today to about $16 \%$ in 2040 ; the public investment 
rate declines from 8\% today to about 6\% in 2040.

\section{1 Comparison with Earlier Projections}

0nly a few studies have examined the interplay between fiscal policy and private saving and investment in Japan. As in my model, these earlier studies generally predict worsening government budget deficits unless there is significant fiscal reform, and declining saving and investment rates as the Japanese population ages. These studies start from the premise that the future path of Japanese government debt is unsustainable unless there is significant fiscal reform. Their reform scenarios are shown in Table 6.

The Economic Planning Agency (1998) study envisages significant cuts in future social security benefits and moderate increases in payroll taxes. Consequently, government saving rises, while private saving falls sharply, as a result of the population aging. The International Monetary Fund (2000) study envisages reductions in social security benefits, sharp cuts in public investment, and increases in payroll and consumption taxes. Consequently, fiscal balances improve dramatically and the debt-to-GDP ratio first stabilizes then plummets. A special feature of the IMF model is that even when income declines, households do not decumulate their assets; thus, the fall in private saving is moderated. Finally, the Japan Center for Economic Research (2001) envisages sharp increases in taxes and cuts in public investment. Consequently, fiscal balance improves, although debt-to-GDP continues to increase slightly owing to sluggish GDP growth.

\section{Conclusion}

The prospects for improvements in the Japanese fiscal situation are grim unless the government carries out significant fiscal reform. For example, under unchanged spending policies taxes would need to increase from the current $28 \%$ of GDP to over $40 \%$ by 2020 for the government to be solvent. Japanese citizens should brace themselves for painful adjustments in the near future, in the form of lower public services and higher taxes.

A resumption of strong growth in real GDP would reduce the need for spending and tax adjustments. For example, if real interest rates are 3\%, a real GDP growth rate of slightly in excess of $3 \%$ can imply falling debt-to-GDP ratios. The analysis here has assumed that real growth averages just 1.2\% per year from 2000 to 2040. This assumes labor-augmenting technical progress of about $1.2 \%$ per year, or total factor 
productivity growth (TFP) growth of $2.0 \%$ per year. TFP growth of $2.0 \%$ is actually an assumption on the high side, as it is about equal to Japan' s average TFP growth between 1970 and 1990, and Japan has not been as innovative it was then (Branstetter and Nakamura, this volume). What lowers GDP growth from $2.0 \%$ to $1.2 \%$ is the dramatic 0. $8 \%$ annual decline in the labor force caused by the aging of the population.

Thus, one way to increase GDP growth is to raise the labor supply. Ono and Rebick (this volume) argue for removals of structural impediments that restrict the movement of labor between firms and discourage women from participating to a greater extent. Another possibility that has received scant attention until now is to promote immigration into Japan. Of high priority are further studies on the impact of increased foreign immigration on Japanese growth, saving, and the government debt.

An aging population does not necessarily mean that Japan will sink into international oblivion. Certainly, Japanese policymakers are aware, not only of the problems associated with aging, but of a slew of proposals to address the problems, both directly, and indirectly, through removing the other impediments to growth discussed in this volume and elsewhere. 


\section{References}

Ando, Albert, Christelis, Dimitrios, and Tsutomu Miyagawa (2002), "Household Savings and Corporate Behavior in the Japanese Economy," in Structural Impediments to Growth in Japan, forthcoming.

Bayoumi, Tamin (1998), “The Japanese Fiscal System and Fiscal Transparency,” in Aghevli, B. et. al. (Ed.), Structural Change in Japan, Washington, D. C., International Monetary Fund.

Branstetter, Lee, and Yoshiaki Nakamura (2002), "Has Japan=s Innovative Capacity Declined," in Structural Impediments to Growth in Japan, forthcoming.

Cutler, David, Poterba, James, Sheiner, Loise, and Lawrence Summers (1990), “An Aging Society: Opportunity or Challenge?” , Brookings Papers on Economic Activity, $1,1-55$.

Dekle, Robert(2002), "Population Aging in Japan: Its Impact on Future Saving, Investment, and Budget Deficits, " Working Paper, Department of Economics, USC. (www. usc. edu/dept/LAS/economics/Pages/faculty/fac_pages/web_dekle.htm)

Doi, Takero and Hoshi, Takeo (2002), "Paying for the FILP” in Structural Impediments to Growth in Japan, forthcoming.

Economic and Social Research Institute. (2002), National Accounts of Japan. Tokyo: Ministry of Finance Printing Office.

Economic Planning Agency, (1998), "Economic Analysis of Japan=s Aging Society," Keizai Bunseki, September.

Fukao, Mitsuhiro( 2002), "Financial Sector Profitability and Double-Gearing” in Structural Impediments to Growth in Japan, forthcoming.

Ihori, Toshihiko, Nakazato, Toru, and Masumi Kawade, (2002), "Japan=s Fiscal Policies in the 1990s," mimeographed, University of Tokyo.

International Monetary Fund (2000), World Economic Outlook, Washington, D. C., International Monetary Fund.

Ishi, Hiromitsu (2000), Making Fiscal Policy in Japan, 0xford: Oxford University Press.

Ishii, Hiroko and Erica Wada (1998), Local Government Spending: Solving the Mystery of Japanese Fiscal Packages, Institute for International Economics, Working Paper 98-5.

Japan Center for Economic Research, (2001), “Long-Run Forecasts of the Japanese Economy, Tokyo: Japan Center for Economic Research.

Jinno, Naohiko, and Masaru Kaneko (2002), Zaisei Hakai o Kuitomeru (Stopping the Deterioration in Fiscal Budgets), Tokyo: Iwanami. 
Muhleisen, Martin (2000), "Sustainable Fiscal Policies for an Aging Population," in Selected Issues, Japan, Washington, D. C.: International Monetary Fund.

Ono, Hiroshi and Mark Rebick( 2002), "Impediments to the Productive Employment of Labor in Japan," in Structural Impediments to Growth in Japan, forthcoming.

Sakurai, Yoshiko (1998), Nihon no Kiki (Japan’s Crisis), Tokyo: Shinchosha. 
Table 1

Japanese Private and Government Saving, Investment, and Net Exports

(in percent of GDP)

\begin{tabular}{cccccc}
\hline \hline & $\begin{array}{c}\text { Private } \\
\text { saving }\end{array}$ & $\begin{array}{c}\text { Government } \\
\text { saving }^{1}\end{array}$ & $\begin{array}{c}\text { Private } \\
\text { Investment }^{2}\end{array}$ & $\begin{array}{c}\text { Public } \\
\text { Investment }\end{array}$ & $\begin{array}{c}\text { Net export } \\
\text { surplus }\end{array}$ \\
\hline $1955-73$ & 13.5 & 9.5 & 17.3 & 7.3 & -1.5 \\
$1974-79$ & 26.3 & 3.1 & 20.7 & 9.2 & -0.6 \\
$1980-90$ & 26.0 & 4.5 & 20.7 & 7.4 & 2.4 \\
$1991-95$ & 26.0 & 5.2 & 21.5 & 7.7 & 1.9 \\
$1996-99$ & 28.4 & 1.6 & 20.3 & 8.0 & 1.8 \\
\hline
\end{tabular}

1 Includes net social security surplus.

2 Includes plant and equipment, housing, and inventory investment.

Source: Economic and Social Research Institute, Annual Report on the National Accounts, 1999 and 2001 editions.

Table 2

0verview of Government Finances (A11 Figures are in Percent of GDP)

\begin{tabular}{rrrrrrrrrrl}
\hline \hline 1990 & 1991 & 1992 & 1993 & 1994 & 1995 & 1996 & 1997 & 1998 & 1999 & \\
\hline 1.9 & 1.8 & 0.8 & -2.4 & -2.8 & -4.1 & -4.9 & -3.7 & -10.7 & -7.0 & Fiscal balance \\
7.2 & 7.2 & 6.7 & 4.7 & 4.2 & 2.9 & 2.6 & 2.6 & 1.2 & 0.0 & Government Saving \\
& & & & & & & & & & Of which: \\
1.3 & 1.7 & 1.6 & 1.4 & 1.2 & 1.2 & 1.1 & 1.2 & 0.8 & 0.4 & Social Security Surplus \\
-3.6 & -3.5 & -3.7 & -3.8 & -3.9 & -4.1 & -4.2 & -4. & -4.2 & -4.3 & Healthcare \\
& & & & & & & 1 & & & \\
9.5 & 9.0 & 8.8 & 7.1 & 7.0 & 5.9 & 5.6 & 5.5 & 4.6 & 3.9 & Other Surplus \\
& & & & & & & & & & \\
65.1 & 64.7 & 67.6 & 72.7 & 78.4 & 85.4 & 91.8 & 97.5 & 108.5 & 120.5 & Gross Debt \\
7.3 & 6.4 & 12.3 & 10.1 & 12.1 & 16.9 & 21.6 & 27.9 & 38.0 & 44.4 & Net Debt $A^{2}$ \\
35.4 & 35.5 & 42.9 & 42.8 & 46.6 & 52.5 & 57.7 & 64.6 & 75.9 & 84.9 & Net Debt B ${ }^{3}$ \\
\hline
\end{tabular}

1 Government Saving plus Net Land Purchases and Net Gift and Inheritance Taxes minus Public Investment

2 Including social security system assets.

3 Excluding social security system assets.

Source: Economic and Social Research Institute, Annual Report on the National Accounts, 2001 edition. 
Table 3

Debt-to-GDP Ratio Dynamics

(in percent of GDP)

Scenario 1: Unchanged Government Policies

\begin{tabular}{cccccc}
\hline \hline Year & Taxes & $\begin{array}{c}\text { Public } \\
\text { investment }\end{array}$ & $\begin{array}{c}\text { Govt } \\
\text { spending }\end{array}$ & Debt if $3 \%^{1}$ & Debt if $6 \%^{2}$ \\
\hline 2000 & 28 & 8 & 25 & 45 & 45 \\
2005 & 28 & 8 & 26 & 80 & 91 \\
2010 & 28 & 8 & 28 & 127 & 157 \\
2015 & 28 & 8 & 28 & 191 & 257 \\
2020 & 28 & 8 & 26 & 262 & 381 \\
2025 & 28 & 8 & 27 & 337 & 508 \\
2030 & 28 & 8 & 27 & 428 & 715 \\
2035 & 28 & 8 & 33 & 540 & 949 \\
2040 & 28 & 8 & 30 & 690 & 1263 \\
\hline
\end{tabular}

Scenario 2: Increased Taxes

\begin{tabular}{ccccccc}
\hline \hline Year & $\begin{array}{c}\text { Public } \\
\text { investment }\end{array}$ & $\begin{array}{c}\text { Govt } \\
\text { spending }\end{array}$ & $\begin{array}{c}\text { Taxes } \\
\text { if } 3 \%^{1}\end{array}$ & $\begin{array}{c}\text { Debt } \\
\text { if } 3 \%^{1}\end{array}$ & $\begin{array}{c}\text { Taxes } \\
\text { if } 6 \%^{2}\end{array}$ & $\begin{array}{c}\text { Debt } \\
\text { if } 6 \%^{2}\end{array}$ \\
\hline 2000 & 8 & 25 & 28 & 45 & 28 & 45 \\
2005 & 8 & 26 & 31 & 81 & 31 & 91 \\
2010 & 8 & 28 & 34 & 111 & 34 & 140 \\
2015 & 8 & 28 & 39 & 141 & 47 & 200 \\
2020 & 8 & 26 & 40 & 149 & 49 & 202 \\
2025 & 8 & 27 & 41 & 141 & 50 & 186 \\
2030 & 8 & 27 & 41 & 134 & 50 & 166 \\
2035 & 8 & 33 & 44 & 130 & 51 & 143 \\
2040 & 8 & 30 & 44 & 129 & 53 & 129 \\
\hline
\end{tabular}

Scenario 3: Cuts in Spending and Investment

\begin{tabular}{cccccc}
\hline \hline Year & Taxes & $\begin{array}{c}\text { Public } \\
\text { investment }\end{array}$ & $\begin{array}{c}\text { Govt } \\
\text { spending }\end{array}$ & $\begin{array}{c}\text { Debt } \\
\text { if } 3 \%^{1}\end{array}$ & $\begin{array}{c}\text { Debt } \\
\text { if } 6 \%^{2}\end{array}$ \\
\hline 2000 & 28 & 8 & 25 & 45 & 45 \\
2005 & 28 & 3 & 22 & 71 & 81 \\
2010 & 28 & 3 & 24 & 67 & 92 \\
2015 & 28 & 3 & 24 & 72 & 116 \\
2020 & 28 & 3 & 22 & 74 & 145 \\
2025 & 28 & 3 & 23 & 70 & 175 \\
2030 & 28 & 3 & 23 & 69 & 213 \\
2035 & 28 & 3 & 27 & 72 & 264 \\
2040 & 28 & 3 & 25 & 93 & 346 \\
\hline
\end{tabular}

1 Assuming a 3\% real interest rate on government debt.

2 Assuming a $6 \%$ real interest rate on government debt. 
Table 4

Projected Government Spending, 2000-2040

\begin{tabular}{|c|c|c|c|c|c|c|c|}
\hline \multirow[b]{2}{*}{ Year } & \multicolumn{3}{|c|}{ In billion 1995 yen } & \multicolumn{3}{|c|}{ In percent of $\mathrm{GDP}^{1}$} & \multirow[b]{2}{*}{ Total } \\
\hline & $\begin{array}{c}\text { Social } \\
\text { security }\end{array}$ & $\begin{array}{c}\text { Health } \\
\text { care }\end{array}$ & $\begin{array}{l}\mathrm{Edu}^{-} \\
\text {cation }\end{array}$ & $\begin{array}{c}\text { Social } \\
\text { security }\end{array}$ & $\begin{array}{c}\text { Health } \\
\text { Care }\end{array}$ & $\begin{array}{l}\mathrm{Edu}^{-} \\
\text {cation }\end{array}$ & \\
\hline 2000 & 57,667 & 27,271 & 16,327 & 10.7 & 5.3 & 3.2 & 24.8 \\
\hline 2005 & 65,265 & 28,471 & 15,634 & 11.9 & 5.4 & 2.9 & 25.8 \\
\hline 2010 & 74,032 & 29,462 & 15,445 & 13.9 & 5.7 & 3.1 & 28.2 \\
\hline 2015 & 78,318 & 30,550 & 15,067 & 14.1 & 5.7 & 2.8 & 28.2 \\
\hline 2020 & 78,903 & 30,659 & 14,689 & 13.2 & 5.1 & 2.4 & 26.3 \\
\hline 2025 & 79,098 & 30,089 & 13,680 & 14.2 & 5.2 & 2.3 & 27.3 \\
\hline 2030 & 79,683 & 29,392 & 12,923 & 14.2 & 5.2 & 2.3 & 27.3 \\
\hline 2035 & 81,630 & 28,764 & 12,167 & 18.3 & 6.3 & 2.7 & 32.9 \\
\hline 2040 & 81,046 & 28,407 & 11,915 & 16. 1 & 5.7 & 2.4 & 29.8 \\
\hline
\end{tabular}

1 GDP projections are from the simulation model in Dekle (2002).

2 Includes 5. 6\% each year for "0ther spending" for defense, policing, administration, etc.

Table 5

Projections of Government Debt, and Private Saving and Investment Rates as Percent of GDP

\begin{tabular}{cccccccc}
\hline \hline & $\begin{array}{c}\text { Support } \\
\text { ratio }\end{array}$ & $\begin{array}{c}\text { Net } \\
\text { debt }\end{array}$ & $\begin{array}{c}\text { Govt } \\
\text { tax } \\
\text { rate }\end{array}$ & $\begin{array}{c}\text { Govt } \\
\text { saving }\end{array}$ & $\begin{array}{c}\text { Private } \\
\text { Saving }\end{array}$ & $\begin{array}{c}\text { Private } \\
\text { invest- } \\
\text { ment }\end{array}$ & $\begin{array}{c}\text { Govt } \\
\text { invest- } \\
\text { ment }\end{array}$ \\
\hline 2000 & 0.63 & 45 & 28 & 1 & 28 & 20 & 8 \\
2005 & 0.61 & 88 & 31 & 0 & 28 & 20 & 8 \\
2010 & 0.59 & 128 & 38 & 2 & 26 & 19 & 7 \\
2015 & 0.57 & 153 & 43 & 6 & 18 & 18 & 7 \\
2020 & 0.56 & 155 & 45 & 10 & 15 & 18 & 7 \\
2025 & 0.55 & 140 & 45 & 9 & 13 & 17 & 6 \\
2030 & 0.54 & 122 & 46 & 10 & 11 & 17 & 6 \\
2035 & 0.54 & 102 & 47 & 7 & 12 & 16 & 6 \\
2040 & 0.52 & 89 & 49 & 13 & 6 & 16 & 6 \\
\hline
\end{tabular}

1 Ratio of labor force to total population. Japanese government estimates.

Source: Dekle 2002. 
Table 6

Earlier Projections of

Japanese Government Debt and Saving and Investment Fiscal Reform Scenarios

(in percent of GDP)

\begin{tabular}{|c|c|c|c|c|}
\hline 2005 & 2010 & 2025 & 2050 & \\
\hline \multicolumn{5}{|c|}{ Economic Planning Agency (1998) } \\
\hline-1.1 & - & -0.5 & 0.3 & Government Saving \\
\hline 32.6 & - & 34.5 & 35.4 & Tax Rate \\
\hline 31.5 & - & 22.6 & 15.2 & Private Saving \\
\hline 32.8 & - & 25.0 & 20.2 & Total Investment \\
\hline \multicolumn{5}{|c|}{ International Monetary Fund (2000) } \\
\hline 62.0 & 62.0 & 50.0 & 30.0 & Net Government Debt1 \\
\hline-6.0 & 2.0 & 3.0 & 0.0 & Fiscal Balance2 \\
\hline 22.0 & 23. 0 & 22.0 & 22.0 & Private Saving \\
\hline \multicolumn{5}{|c|}{ Japan Center for Economic Research (2001) } \\
\hline 149 & 163 & 187 & - & Gross Debt \\
\hline-6.0 & -5.0 & -2.1 & - & Fiscal Balance \\
\hline 46. 0 & 47.3 & 49.9 & - & Tax Rate \\
\hline
\end{tabular}

1 Government Gross Debt minus Gross Assets.

2 Government Saving minus Public Investment. 
Figure 1: Population and Ederly Projections

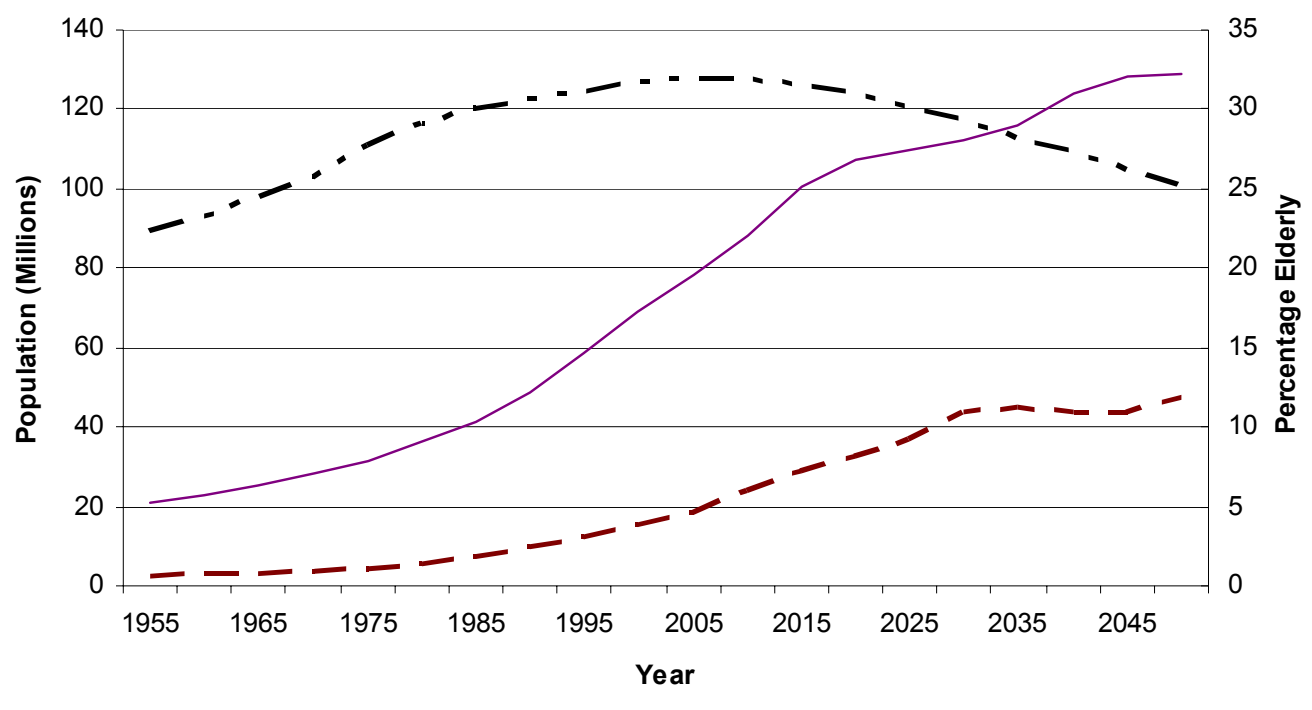

- - - Population — Over $65-$ - Over 80 